\title{
Les résultats principaux de 100 ans de recherche au Vernagtferner, Oetztal (Autriche)
}

\author{
L. N. Braun \\ Commission for Glaciology, Bavarian Academy of Sciences
}

The glacier with the longest record of observations in the Eastern Alps is Vernagtferner, situated in the Oetztal valley in Austria. In the last 400 years, the glacier advanced four times down to the main Rofen valley (2 $130 \mathrm{~m}$ a.s.l.) with the result that it blocked the valley and formed a lake upstream (fig. I, fig. 2a). Several catastrophic outburst floods are reported causing severe damage downstream. About 100 years ago systematic surveying of this dangerous glacier was started by Sebastian Finsterwalder, and by applying the photogrammetric technique over the whole glacier, the first accurate map was produced in 1889, when the glacier tongue was at an elevation of $2514 \mathrm{~m}$ [1]. Based on this mapping and additional measurements and observations Finsterwalder [2] published the first descriptive theory of glacier movement, a fundamental contribution to glacier research. Further surveyings were performed in $1912,1938,1954,1969,1979$ and 1990 , and the respective volume balances derived [3], (fig. 2b). The general loss in ice volume was interrupted by a gain during the two intervals between 1954 and 1979 (mean rise of 14 and $29 \mathrm{~cm} / \mathrm{y}$, respectively). This mass gain gave rise to a surgelike glacier movement during the 1979 to 1982 period, where a detailed assessment of the spatial distribution of elevation changes was made [4]. The surges of Vernagtferner in historical time are described by HOINKES [5].

In 1965 the Vernagtferner was included in a combined balances project of the International Hydrological Decade (IHD) under the initiative of F. Hoinkes, and annual glacier mass balances have been determined since then (fig. $2 c$, fig. 3). In 1973 the gauging station « Pegelstation Vernagtbach " was constructed at an elevation of $2640 \mathrm{~m}$, draining a basin of $11.44 \mathrm{~km}^{2}$ with a glacierization of approx. $80 \%$. Discharge has been monitored since then at a temporal resolution of one hour, which allowed a detailed analysis of runoff processes ( $\mathrm{fig} .2 d$ ). In a joint research programme during the period of 1974 to 1986 of the Commission for Glaciology at the Bavarian Academy of Sciences and the GSF-Institute for hydrology, Munich, the energy balance including the meltwater production at the glacier surface was determined, and the drainage within and beneath the glacier studied intensively. A detailed summary of the results of this programme is given by MOSER et al. [6], the latest research activities and a description of the data base are given by REINWARTH [7] and ESCHER-VETTER and REINWARTH [8].

Due to the remarkable glacier mass losses since the early 1980s (fig. 3), the firn region of Vernagtferner has been greatly reduced to less than one-tenth of its original size. As a result, temporary storage of meltwater in the firn is

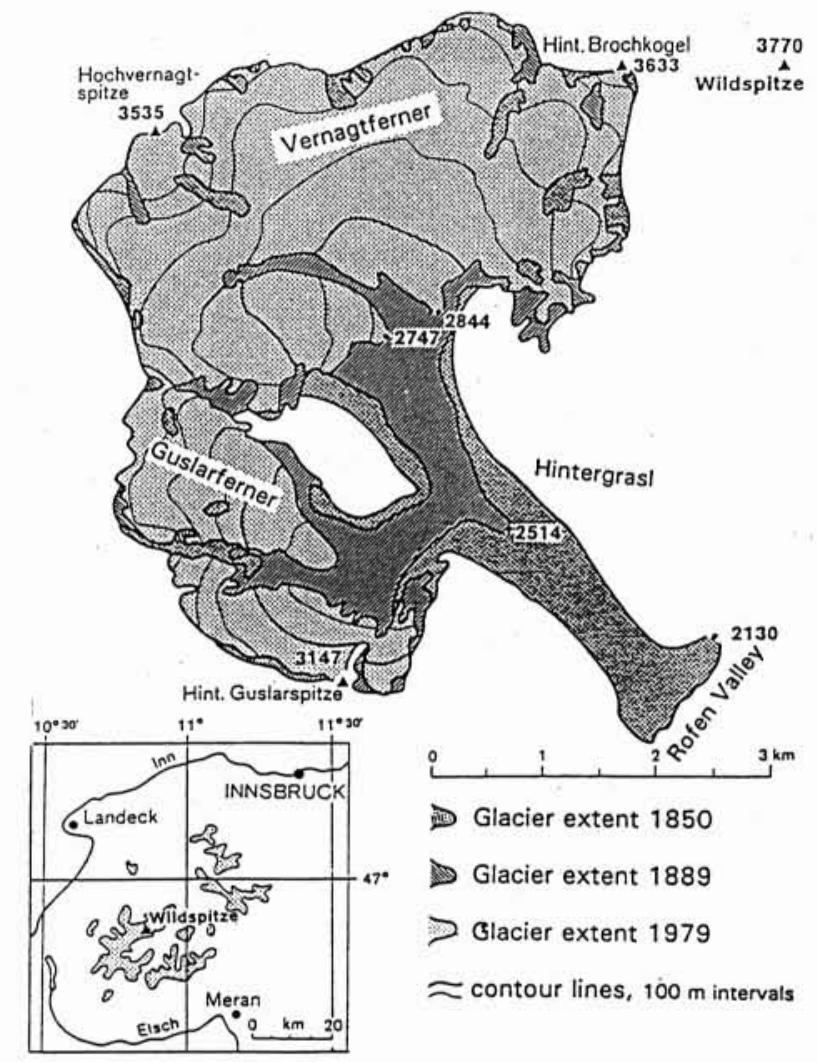

1. Extent of Guslar- and Vernagtferner at the historical maximum (approx. 1850) and the mapped stages of 1889 and 1979 (figure taken from [3]).

strongly diminished, and the diurnal fluctuations of discharge have increased dramatically during the past 5 years. The measuring capacity of the gauging station of $10 \mathrm{~m}^{3} / \mathrm{s}$ was repeatedly surpassed by $50 \%$ in August 1994 , causing damage to the station and the first significant data loss. Preparations are under way to adapt the gauging station to these altered runoff conditions.

\section{Selected References}

[1] BRUNNER K. (1993). - Die Karte Der Vernagtferner im Jahre 1889 als erste exakte Kartierung eines Gesamtgletschers. Zeitschrift für Gletscherkunde und Glazialgeologie, Bd. 29, H. 1, pp. 93-98. 


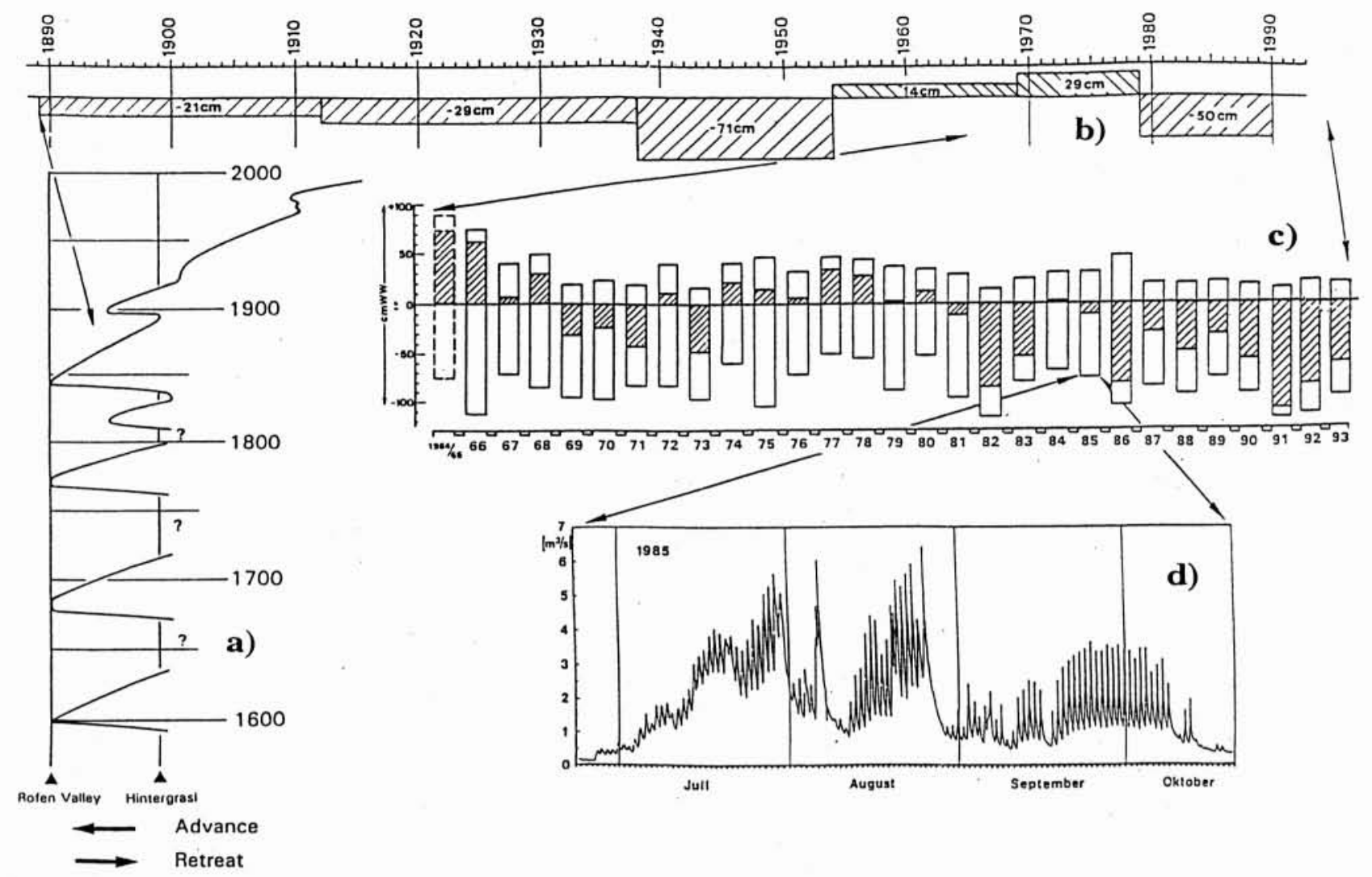

2. Changes of Vernagtferner as given by

a) length observations, and as derived from balance measurements using the

b) geodetic method : mean annual elevation change $(\mathrm{cm} / \mathrm{y})$;

c) glaciological method : specific annual net accumulation (+), ablation (-) and net mass balance (shaded), given in cm water equivalent ;

d) hydrological method : runoff hydrograph $\left(\mathrm{m}^{3} / \mathrm{s}\right)$ for the ablation season of 1985 as an example (figure taken from [3]).

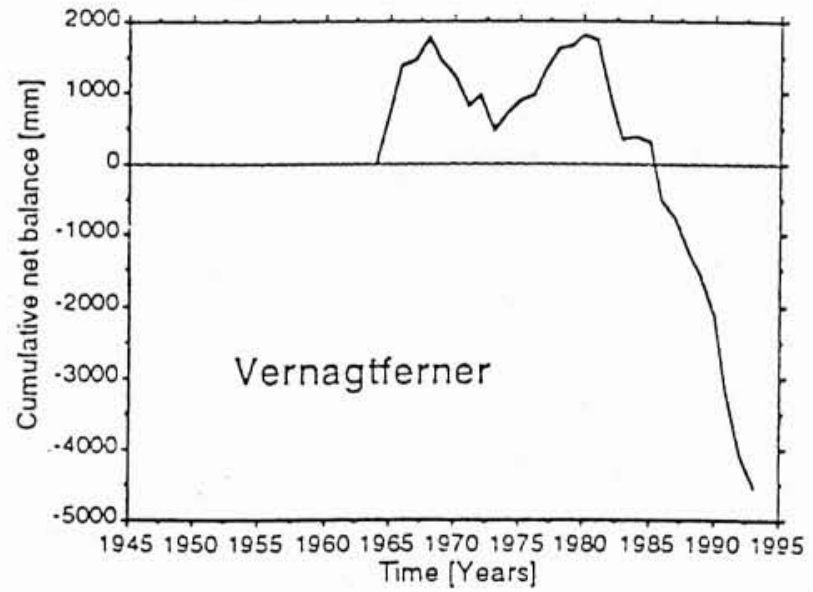

3. Cumulative net balance of Vernagtferner $1964 / 65$ to $1992 / 93$.

[2] Finsterwalder S. (1897). - Der Vernagtferner. Wiss. Ergänzungsheft zur Zeitschrift des Deutschen und Oesterreichischen Alpenvereins, 1. Bd., 2. Heft, pp. 5-96.
[3] Reinwarth O. and RentsCh H. (1995). - Volume and mass balance of Vernagtferner/Oetztal Alps. Zeitschrift für Gletscherkunde und Glazialgeologie, accepted for publication.

[4] Reinwarth (1993a) Vernagtferner (1979-1982). - Austria, $1: 10$ '000 (thematic map). Fluctuations of Glaciers, Vol. VI, compiled by W. Haeberli, pp. 93-95.

[5] HOINKES H. (1969). - Surges of Vernagtferner in the Oetztal Alps since 1599. Canad. J. Earth Sci. 6(4), pp. 853-861.

[6] Moser H., Escher-Vetter H., Oerter,, H., Reinwarth O. and ZUNKE D. (1986). - Abfluss in und von Gletschern. GSF-Bericht 41/86, Teil I und II, Gesellschaft für Strahlenund Umweltforschung München, 409 p. and 147 p.

[7] ReINWARTH O. (1993b). - Glaciological research at Vernagtferner/Oetztal Alps : database and results of a hydrological subprogramme. IAHS Publ. no. 218, pp. 193-205.

[8] Escher-Vetter H. and Reinwarth O. (1995). - Two de cades of runoff measurements (1974-1993) at the Pegelstation Vernagtbach/Oetztal Alps. Zeitschrift für Gletscherkunde und Glazialgeologie, accepted for publication. 